\title{
ARAŞTIRMA / RESEARCH \\ Pediatric urinary stone disease: experience from a Turkish tertiary referral center
}

Çocuklarda üriner taş hastalığı: Türkiye'deki bir üçüncü basamak merkez deneyimi

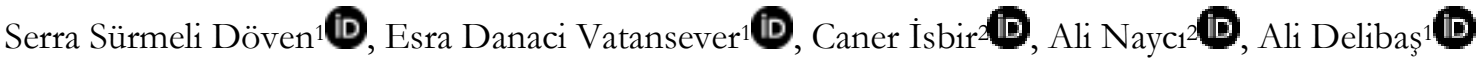

${ }^{1}$ Mersin Üniversitesi Tıp Fakültesi, Çocuk Sağlığı ve Hastalıkları Anabilim Dalı, Çocuk Nefroloji Bilim Dalı, ${ }^{2}$ Mersin Üniversitesi Tıp Fakültesi, Çocuk Cerrahisi Anabilim Dalı, Çocuk Üroloji Bilim Dalı, Mersin, Turkey

\begin{tabular}{|c|c|}
\hline \multicolumn{2}{|c|}{ Cukurova Medical Journal 2022;47(1):44-49 } \\
\hline Abstract & $\ddot{O} z$ \\
\hline $\begin{array}{l}\text { Purpose: The incidence of pediatric } \\
\text { nephrolithiasis/urolithiasis (NL/UL) has increased in the } \\
\text { last few decades due to dietary habits and a sedentary } \\
\text { lifestyle. This study aimed to determine the etiological } \\
\text { factors and six months of follow-up results of patients with } \\
\text { NL/UL in pediatric nephrology and urology clinics in our } \\
\text { center. }\end{array}$ & $\begin{array}{l}\text { Amaç: Çocuklarda böbrek taşı sıklı̆̆ı, son zamanlarda } \\
\text { beslenme alışkanlıklarındaki değişikliklere ve sedanter } \\
\text { yaşama bağlı olarak artış göstermiştir. Bu çalışmada, } \\
\text { merkezimizde Çocuk Nefroloji ve Çocuk Üroloji } \\
\text { Klinikleri'nde böbrek taşı/üreter taşı (BT/ÜT) tanılarıyla } \\
\text { takip edilen hastaların etiyolojik faktörlerini ve altı aylık } \\
\text { izlem sonuçlarını değerlendirmek amaçlandı. }\end{array}$ \\
\hline $\begin{array}{l}\text { Materials and Methods: Children with NL/UL between } \\
\text { December } 2018 \text { and December } 2020 \text { were enrolled in this } \\
\text { study. The medical records were reviewed to collect data } \\
\text { about admission complaints, consanguinity, metabolic risk } \\
\text { factors for NL/UL, medical treatments, surgical } \\
\text { interventions, and presence of stones after } 6 \text { months of } \\
\text { follow-up. }\end{array}$ & $\begin{array}{l}\text { Gereç ve Yöntem: Aralı 2018- Aralık } 2020 \text { arasında } \\
\text { BT/ÜT tanılarıla Çocuk Nefroloji ve Üroloji } \\
\text { Klinikleri'nde takip edilen hastalar çalışmaya dahil edildi. } \\
\text { Hastaların başvuru şikayetleri, anne-baba akrabalığ1, } \\
\text { BT/ÜT açısından metabolik risk faktörleri, aldıkları } \\
\text { tedaviler, cerrahi operasyonlar ve taşların varlığının } 6 \text { aylık } \\
\text { takip sonucunda devam edip etmediği bilgileri kayıtlardan }\end{array}$ \\
\hline $\begin{array}{l}\text { Results: A total of } 93 \text { patients ( } 46 \text { male and } 47 \text { female) } \\
\text { were included in the study. Consanguinity and a positive } \\
\text { family history for stones was present in } 46.2 \% \text { and } 78.5 \% \\
\text { of patients, respectively. The urinary metabolic risk factors } \\
\text { were hyperuricosuria }(11 / 83,13.3 \%) \text {, hypercalciuria } \\
(12 / 93,12.9 \%) \text {, hyperoxaluria }(6 / 51,11.8 \%) \text {, cystinuria } \\
(7 / 90,7.8 \%) \text {, and hypocitraturia }(2 / 41,4.9 \%) \text {. Twenty } \\
\text { patients }(29.9 \%) \text { with NL/UL and without cystinuria } \\
\text { received potassium citrate therapy. After } 6 \text { months of } \\
\text { follow-up }(n=27) \text { of these patients, stone progression was } \\
\text { not observed in any of the patients who received } \\
\text { potassium citrate treatment }(n=11) \text { or underwent surgical } \\
\text { intervention }(n=10) \text {. }\end{array}$ & 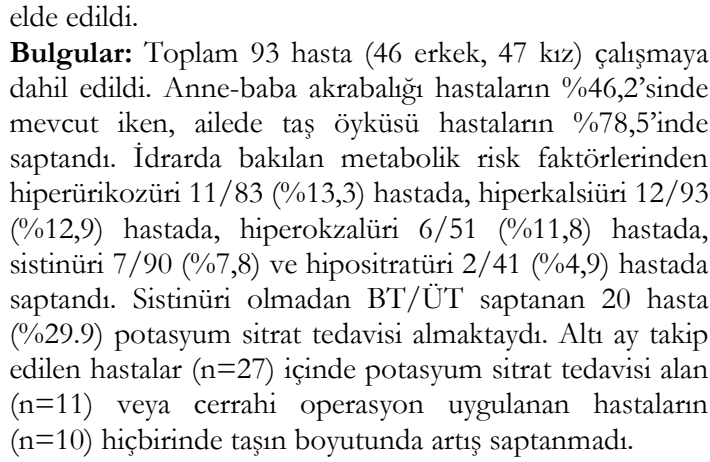 \\
\hline $\begin{array}{l}\text { Conclusions: Most patients had a family history of stones. } \\
\text { Hyperuricosuria was the most common urinary risk factor } \\
\text { for NL/UL. Potassium citrate therapy might be useful to } \\
\text { prevent stone progression in patients with NL/UL. }\end{array}$ & $\begin{array}{l}\text { Sonuç: Hastaların çoğunda ailede taş öyküsü saptandi. } \\
\text { Hiperürikozüri, BT/ÜT için en sk görülen risk } \\
\text { faktörüydü. Potasyum sitrat tedavisi BT/ÜT'li hastalarda } \\
\text { taş progresyonunun önlenmesinde faydalı olabilir. }\end{array}$ \\
\hline $\begin{array}{l}\text { Keywords:. Childhood, nephrolithiasis, potassium citrate, } \\
\text { urolithiasis }\end{array}$ & $\begin{array}{l}\text { Anahtar kelimeler: Böbrek taşı, çocukluk çağı, potasyum } \\
\text { sitrat, üreter taşı }\end{array}$ \\
\hline
\end{tabular}




\section{INTRODUCTION}

The incidence of nephrolithiasis (NL) has significantly increased among pediatric patients in recent years ${ }^{1}$. The reasons for this increase are sedentary lifestyle, increased sodium intake, decreased calcium and water intake as well use of drugs such as corticosteroids, diuretics and anticonvulsants ${ }^{2}$. The reported incidence of NL is $5 \%-15 \%$ in developing and $1 \%-5 \%$ in developed countries $^{3}$. Pediatric NL is rare compared with adult NL, and children constitute $2 \%-3 \%$ of all patients with NL. Though there are some studies reporting a higher incidence among boys, others reported an equal ratio in both sexes, ${ }^{4}$. The mean age at the diagnosis was seven years among girls and five years among boys. A family history of stones existed in $12 \%-68 \%$ of the patients ${ }^{6}$.

Urinary system stones are etiologically divided into four groups: anatomical stones (urinary anomalies: $8 \%-32 \%$ ), metabolic stones (33\%-95\%) (calcium, uric acid, and cystine stones), infection stones (2\%$24 \%$ ), and idiopathic stones $(1 \%-5 \%)$. Conditions causing calcium stones are hypercalciuria, hyperoxaluria, hyperuricosuria, hypocitraturia, and hypomagnesemia. Uric acid stones occur due to hereditary reasons, excessive uric acid production, and hyperuricosuria whereas cystine stones occur in cystinuria ${ }^{3}$. The most common stones are calcium oxalate and calcium phosphate stones, and the most common risk factors are hypercalciuria and hypocitraturia?.

Pediatric NL can be treated medically and surgically. Stones up to $1 \mathrm{~cm}$ usually do not cause any obstruction or infection in the urinary system and can be followed up by ultrasonography (USG). Specific treatments for metabolic problems is beneficial for both preventing the formation of new stones and dissolving the existing ones. Potassium citrate (1-2 $\mathrm{meq} / \mathrm{kg}$ ) increases the citrate level in the urine and reduces the risk of stone formation by alkalizing the urine. It can be used in patients who have metabolic abnormalities such as cystinuria, hypercalciuria, hyperuricosuria and hypocitraturia. In a recent study, the reported recurrence rate was $16.6 \%$ in children who treated with potassium citrate after complete removal of cystine stones while the recurrence was $100 \%$ in children who received no preventive treatment ${ }^{8}$. Thiopronine can be used to reduce the level of cystine in urine in patients with cystinuria.
The surgical treatment options are available for pediatric NL patients including stone crushing (extracorporeal shock wave lithotripsy or ESWL), endoscopic interventions (ureterorenoscopy (URS)retrograde intrarenal surgery-transurethral cystolithotripsy), percutaneous interventions, laparoscopic surgery, and open stone surgery. Although endoscopic methods are commonly and successfully used in the surgical treatment of urinary system stones, open surgery is required in some cases. Open surgery indications are as follows: Failure in minimally invasive procedures, presence of additional urinary system anomalies (such as ureteropelvic stenosis), severe skeletal anomaly, $>30 \mathrm{~mm}$ stone in the bladder as well complex and complete staghorn stones in young children ${ }^{3}$.

Although the etiological factors of stones were reported several times previously, follow-up results and the effect of potassium citrate treatment on stone progression were reported in a few studies. This study aimed to evaluate the etiological factors, follow-up, and treatment among children with NL and urolithiasis (UL), the effect of potassium citrate treatment on stone presence and progression who were followed in Pediatric Nephrology and Pediatric Urology Clinics at the Mersin University Faculty of Medicine.

\section{MATERIAL AND METHODS}

\section{Sample}

Children with (NL/UL) and nephrocalcinosis between December 2015 and December 2020 were enrolled to this study. The local ethics committee has approved the study $(2021 / 271)$. The study was conducted in conformity with the principles of the Declaration of Helsinki. Patients between 1 and 18 years diagnosed with NL/UL, and those who had medical records of admission complaints, consanguinity, metabolic risk factors for NL/UL, medical treatments, and surgical intervention between December 2018 and December 2020, were enrolled in the study. Patients who had incomplete or had not medical records, and those younger than 1 year or older than 18 years were excluded from the study. In total 258 patients who were admitted to Departments of Pediatric Nephrology and Pediatric Surgery between December 2018 and December 2020, were evaluated. Of patients, 165 were excluded because medical records were absent or incomplete. 
Ninety three patients who fulfilled inclusion and exclusion criteria were enrolled to the study.

Table 1. Normal solute concentration levels of urine in children

\begin{tabular}{|c|c|c|}
\hline & Age & $\begin{array}{c}\text { Spot urine } \\
\text { solute/creatinine } \\
\text { ratio levels (mg/mg) }\end{array}$ \\
\hline \multirow[t]{6}{*}{ Calcium } & $0-6$ months & $<0.8$ \\
\hline & 7-12 months & $<0.6$ \\
\hline & $1-3$ years & $<0.53$ \\
\hline & 3-5 years & $<0.39$ \\
\hline & 5-7 years & $<0.28$ \\
\hline & $>7$ years & $<0.21$ \\
\hline \multirow[t]{5}{*}{ Oxalate } & $0-6$ months & $<0.28$ \\
\hline & 7-24 months & $<0.11$ \\
\hline & $2-5$ years & $<0.08$ \\
\hline & $6-14$ years & $<0.06$ \\
\hline & $>16$ years & $<0.03$ \\
\hline \multirow[t]{2}{*}{ Citrate } & $\leq 5$ years & $>0.42$ \\
\hline & $>5$ years & $>0.25$ \\
\hline \multirow[t]{5}{*}{ Uric acide } & $<1$ year & $<2.2$ \\
\hline & $1-3$ years & $<1.9$ \\
\hline & $3-5$ years & $<1.5$ \\
\hline & $5-10$ years & $<0.9$ \\
\hline & $>10$ years & $<0.6$ \\
\hline \multirow[t]{3}{*}{ Cystine } & $<1$ month & $<0.18$ \\
\hline & 1-6 months & $<0.11$ \\
\hline & $>6$ months & $<0.038$ \\
\hline
\end{tabular}

\section{Diagnosis and treatment procedure}

The medical records were reviewed to collect data about admission complaints, consanguinity, metabolic risk factors for NL/UL, medical treatments, and presence of surgical intervention of the patients. Ultrasonography and/or computed tomography in some cases were used to diagnose NL/UL. Urinary tract infection diagnosis was defined as pyuria (more than five white blood cells per high-power field) and positive urine culture (i.e., $>105$ colony-forming units/milliliter of a microorganism).

The diagnosis of nephrocalcinosis was based on the identification of increased echogenicity on USG. Kidney stone was diagnosed in presence of echogenic foci accompanied by sharp acustic shadowing on USG. Hypercalciuria, hyperoxaluria, hypocitraturia, hyperuricosuria and cystinuria were diagnosed based on above the upper limit of spot urine solute/creatinine ratio ${ }^{9}$ levels as shown in Table 1.

Potassium citrate therapy was given to the patients who had metabolic risk factors such as hypercalciuria, hyperuricosuria, hypocitraturia and/or cystinuria. $\mathrm{E} S W L$ was performed in patients whose stones were $10-15 \mathrm{~mm}$ in size and localized in parenchyma and pelvis-calyx, leading to hydronephrosis. URS was performed in symptomatic patients who had ureteral stones larger than $5 \mathrm{~mm}$ in size. Open surgery was performed in patients who had stones larger than 15 $\mathrm{mm}$ in size with hydronephrosis.

Stone absence, stone regression, stone stability, and stone progression were defined as no stone observation in USG, shrinkage in stone diameter, stone with a constant diameter, and an increase in the stone diameter, respectively.

Patients with NL/UL was separated into three groups as having nephrocalcinosis, having cystinuria and having neither nephrocalcinosis nor cystinuria. The patients who received potassium citrate treatment or surgical intervention was compared to the patients who did not receive any treatment in terms of stone presence after 6 months of follow-up.

\section{Statistical analysis}

Data analysis was conducted using the IBM Statistical Package, version 21.0 (IBM SSPS Corp., Armonk, NY, USA) software. Descriptive statistics were expressed as mean and standard deviation. The dependency between categorical variables was tested using Fisher's exact chi-square test was used to compare the patients who were on potassium citrate therapy and who were not on therapy in terms of stone presence after six months of follow-up. An independent-sample $t$ test was used to compare the means of stone diameter of patients with cystinuria and without cystinuria. A $P$ value $<0.05$ indicated a statistically significant difference.

\section{RESULTS}

A total of 93 patients (46 male and 47 female) were included in the study. The mean age of the patients was $64.35 \pm 53.61$ (3.00-192.00) months. Admission complaints were restlessness (26.9\%), abdominal pain/renal colic $(30.1 \%)$, crying while urinating $(16.0 \%)$, hematuria $(10.7 \%)$, inability to gain weight $(3.2 \%)$, fever $(2.2 \%)$, vomiting $(2.2 \%)$, anorexia $(2.2 \%)$, stone drop $(1.1 \%)$ while remaining $5.4 \%$ of the patients were asymptomatic. Ultrasonography and $\mathrm{BT}$ used for NL/UL diagnosis in 13 patients who undergone surgical intervention while USG was used for others. In 35 patients $(37.6 \%)$, the presence of stones was accompanied by urinary tract infections. 
Prematurity and hospitalization history in the neonatal period occurred in $21.5 \%$ and $32.3 \%$ of the patients, respectively. Consanguinity and family history of stones were present in $46.2 \%$ and $78.5 \%$ of the patients, respectively. The metabolic risk factors for stones are shown in Table 1. Although 38 patients had one metabolic risk factor, 32 had two metabolic risk factors accompanied by NL/UL (Table 2). Thirtysix patients $(38.7 \%)$ received potassium citrate treatment.

Serum vitamin $\mathrm{D}$ and parathormone levels were available in $61(65.6 \%)$ and $69(74.2 \%)$ patients, respectively. Vitamin D intoxication, hyperparathyroidism or primary hyperoxaluria were not detected in none of the patients. Mean levels of vitamin $\mathrm{D}$ and parathyroid were $23.58 \pm 11.10 \mathrm{ng} / \mathrm{dl}$ and $37.01 \pm 19.10 \mathrm{pg} / \mathrm{ml}$, respectively.

Table 2. Metabolic risk factors for stones

\begin{tabular}{|l|c|c|c|}
\hline Risk factors & $\mathbf{N}$ & $\begin{array}{c}\text { Patients } \\
\text { with data }\end{array}$ & $\mathbf{\%}$ \\
\hline $\begin{array}{l}\text { Single urinary risk } \\
\text { factors }\end{array}$ & 11 & 83 & 13.3 \\
\hline Hyperuricosuria & 12 & 93 & 12.9 \\
\hline Hypercalciuria & 6 & 51 & 11.8 \\
\hline Hyperoxaluria & 7 & 90 & 7.8 \\
\hline Cystinuria & 2 & 41 & 4.9 \\
\hline Hypocitraturia & 7 & 72 & 15.3 \\
\hline $\begin{array}{l}\text { Multiple risk } \\
\text { factors }\end{array}$ & 71 & 13.7 \\
\hline $\begin{array}{l}\text { Hypercalciuria }+ \\
\text { hyperuricosuria }\end{array}$ & 11 & 8.9 \\
\hline $\begin{array}{l}\text { Hyperuricosuria }+ \\
\text { hyperoxaluria }\end{array}$ & 78 & 10.4 \\
\hline $\begin{array}{l}\text { Hyperuricosuria }+ \\
\text { cystinuria }\end{array}$ & 7 & 46 & 1.2 \\
\hline $\begin{array}{l}\text { Hypercalciuria }+ \\
\text { hyperoxaluria }\end{array}$ & 5 & 2.2 \\
\hline $\begin{array}{l}\text { Hypercalciuria }+ \\
\text { cystinuria }\end{array}$ & 1 & 78 \\
\hline $\begin{array}{l}\text { Hyperuricosuria }+ \\
\text { hypocitraturia }\end{array}$ & 1 & 78 \\
\hline
\end{tabular}

Nephrocalcinosis with urolithiasis was detected in 10 $(10.8 \%)$ patients. All those patients had hypercalciuria, while three $(30 \%)$ had hypercalcemia additionally. Bartter syndrome was diagnosed in one of those patients $(10 \%)$ while others had no detectable underlying disease.

Sixty-seven patients $(72.0 \%)$ did not have cystinuria and nephrocalcinosis. One stone was present in 29 $(43.3 \%)$ patients, while $38(56.7 \%)$ patients had multiple stones. The mean diameter of stones was
$5.45 \pm 3.78 \mathrm{~mm}$. The stones were localized in the parenchyma, pelvis-calyx, lower pole, ureter, and bladder [39 $(58.2 \%), 21(31.4 \%), 5(7.5 \%)$, and 2 (3\%), respectively]. Hydronephrosis was detected in $17(25.4 \%)$ patients; $20(29.9 \%)$ patients received potassium citrate treatment. Thiazide diuretic for hypercalciuria was given to two $(3 \%)$ patients. Surgical intervention was performed in 13 (19.4\%) patients (Table 3).

Table 3. Modality of surgical interventions for stones $(n=13)$

\begin{tabular}{|l|c|c|}
\hline & $\boldsymbol{N}$ & $\mathbf{\%}$ \\
\hline ESWL & 5 & 38.5 \\
\hline URS & 5 & 38.5 \\
\hline Open surgery & 3 & 23.0 \\
\hline $\begin{array}{l}\text { ESWL, Extracorporeal } \\
\text { ureterorenoscopy. }\end{array}$ & shock wave & lithotripsy; URS, \\
\hline
\end{tabular}

Eleven of the patients $(40.7 \%)$ who followed up for 6 months $(n=27)$ received potassium citrate treatment (Table 4). Stone progression was not observed in any of the patients who received potassium citrate treatment or underwent surgical intervention. No significant difference was detected between patients receiving potassium citrate treatment and those not undergoing treatment for the presence of stones $(P=1.000)$.

Table 4. Status of the stones after 6 months of followup in patients who received potassium citrate and/or underwent surgical intervention $(n=27)$

\begin{tabular}{|c|c|c|c|}
\hline $\begin{array}{c}\text { Stone } \\
\text { status }\end{array}$ & $\begin{array}{c}\text { Potassiu } \\
\mathbf{m} \text { citrate } \\
\mathbf{( n = 1 1 )}\end{array}$ & $\begin{array}{c}\text { Surgical } \\
\text { intervention } \\
\mathbf{( n = 1 0 )}\end{array}$ & $\begin{array}{c}\text { Potasssium } \\
\text { citrate+ } \\
\text { surgical } \\
\text { interventio } \\
\mathbf{n}(\mathbf{n}=\mathbf{6})\end{array}$ \\
\hline Absent & $4(36.4 \%)$ & $5(50.0 \%)$ & $6(100.0 \%)$ \\
\hline $\begin{array}{c}\text { Regressi } \\
\text { on }\end{array}$ & $3(27.3 \%)$ & $5(50.0 \%)$ & $0(0.0 \%)$ \\
\hline Stability & $4(36.4 \%)$ & $0(0.0 \%)$ & $0(0.0 \%)$ \\
\hline
\end{tabular}

Of the 27 patients, 6 patients $(22.2 \%)$ received both potassium citrate treatment and underwent surgical intervention. Stones were not detected in these patients after 6 months of follow-up.

After 6 months of follow-up, no significant difference was observed between patients who underwent surgical intervention and those who did not undergo surgery for the stones $(P=0.415)$.

Sixteen patients had cystinuria. The localization of the stones in the parenchyma, pelvis-calyx, and 
bladder was $13(81.3 \%), 2(12.5 \%)$, and one $(6.2 \%)$, respectively. The mean diameter of stones was $8.1 \pm$ $5.62 \mathrm{~mm}$. No significant difference in stone diameter was detected between patients with cystinuria $(n=$ 16) and others $(n=67)(P=0.057)$. Three $(18.8 \%)$ patients needed a second surgery for stones.

Of the patients with cystinuria $(n=16), 10(62.5 \%)$ received tiopronin and $13(81.3 \%)$ received potassium citrate treatment. Surgical intervention was performed in 10 out of $16(62.5 \%)$ patients with cystinuria: open surgery in eight and SWL in two patients. Three patients had only one stone (18.8\%), while 13 patients had multiple stones $(81.3 \%)$.

\section{DISCUSSION}

This study demonstrated that NL/UL was seen especially in patients who had a family history for stones $(78.5 \%)$. Although a large number of epidemiologic studies on NL/UL have been conducted, very few studies have evaluated the effect of potassium citrate treatment on NL/UL. The present study has indicated that potassium citrate treatment was ineffective for the presence of stones. However, regression and stability in stone diameter were detected in 7 of 11 patients (63.6\%) who received potassium citrate treatment; still, progression was not seen in any of the patients. Therefore, the findings of this study revealed that potassium citrate treatment was useful to prevent stone progression.

Hypercalciuria is the most common urinary risk factor for NL/UL ${ }^{10,11}$. Spivacow et $\mathrm{al}^{7}$ found that idiopathic hypercalciuria (alone or combined) was a risk factor $(47.0 \%)$, followed by hypocitraturia $(39.6 \%)$ (alone or combined) and hyperuricosuria (alone or combined) (19.4\%). In the present study, hyperuricosuria and hypercalciuria ratios were found to be lower $(13.3 \%$ and $12.9 \%$, respectively) because they were single risk factors, not combined.

Citrate is an important inhibitor of lithogenesis ${ }^{12,13}$, it reduces urinary saturation because it forms complexes with calcium, inhibits stone nucleation, and delays oxalate crystal aggregation ${ }^{14}$. Potassium citrate therapy is recommended for patients with low urinary citrate and recurrent calcium stones ${ }^{15,16}$. Potassium citrate was found to be protective against the recurrence of NL after ESWL treatment and have an important role to prevent kidney stone formation in a meta-analyse ${ }^{17}$. In the present study after six months of potassium citrate therapy $(n=11)$, four patients had no stone, three patients had regression in stone diameter, four patients were stable. If the follow-up time was longer, potassium citrate therapy might found to be more effective in regression or stone presence.

Stone recurrence is an important problem for children. Residual stones measuring $<5 \mathrm{~mm}$ after surgical intervention have been shown to lead to clinical symptoms in $69 \%$ of patients ${ }^{18}$. Therefore, being stone-free after surgery should be aimed ${ }^{3}$. Although ESWL has a lot of advantages, such as noninvasiveness, short hospitalization period, and low complication ratio, the presence of residual stones is an important disadvantage. In the present study, stones were not detected in $50 \%$ of patients while $50 \%$ had residual stones after six months of surgical intervention. Patients with residual stones underwent ESWL operation as expected.

Cystinuria is an autosomal recessive disorder, leading to recurrent UL with significant morbidity due to obstruction, infection, and repeated surgical intervention ${ }^{19}$. Patients with cystinuria were found to have larger stones at the time of diagnosis, with higher new stone formation rates, and were at higher risk for surgery ${ }^{20}$. Although no statistically significant difference was observed between patients with cystinuria and others, stone diameter was obviously higher in patients with cystinuria $[8.1 \pm 5.62$ vs $5.45 \pm 3.78]$ and a second surgery was needed in $18.8 \%$ of patients with cystinuria, consistent with the previous literature.

The limitation of this study was its retrospective design with a low number of patients. The urinary metabolic risk factors could not be evaluated in all patients. Prospective studies with larger sample size may provide more information regarding the etiology and follow-up results of NL/UL.

In conclusion, a positive family history of stones is commonly seen in patients with NL/UL. Ultrasonography should be performed in patients with a positive family history for stones to confirm the diagnosis. Potassium citrate therapy may prevent stone progression in patients with NL/UL.

\footnotetext{
Yazar Katkıları: Calısma konsepti/Tasarımı: SSD, AD, AN; Veri toplama: SSD, EDV, Cí; Veri analizi ve yorumlama: SSD, AN, AD; Yazı taslağı: SSD; İçeriğin eleştirel incelenmesi: AN, AD; Son onay ve sorumluluk: SSD, EDV, CI, AN, AD; Teknik ve malzeme desteği: SSD, EDV, CI; Süpervizyon: AD, AN; Fon sağlama (mevcut ise): yok. Etik Onay: Bu çalıșma için Mersin Üniversitesi Rektörlüğü Klinik Araştırmalar Etik Kurulundan 31.03.2021 tarih ve 271/07 sayılı kararı ile etik onay alınmıştır.

Hakem Değerlendirmesi: Dış bağımsız.
} 
Finansal Destek: Yazarlar finansal destek beyan etmemișlerdir. Author Contributions: Concept/Design : SSD, AD, AN; Data acquisition: SSD, EDV, CI; Data analysis and interpretation: SSD, AN, AD; Drafting manuscript: SSD; Critical revision of manuscript: AN $\mathrm{AD}$; Final approval and accountability: SSD, EDV, CI, AN, AD Technical or material support: SSD, EDV, CI; Supervision: AD, AN; Securing funding (if available): $\mathrm{n} / \mathrm{a}$

Ethical Approval: For this study, ethical approval was obtained from the Mersin University Rectorate Clinical Research Ethics Committee with the decision dated 31.03.2021 and numbered 271/07.

Peer-review: Externally peer-reviewed.

Conflict of Interest: Authors declared no conflict of interest.

Financial Disclosure: Authors declared no financial support

\section{REFERENCES}

1. Sas DJ. An update on the changing epidemiology and metabolic risk factors in pediatric kidney stone disease. Clin J Am Soc Nephrol. 2011;6:2062-8.

2. Yousefichaijan P, Azami M, Ranjbaran M, Azami S, Rahmati S. Clinical signs, causes, and risk factors of pediatric kidney stone disease: a hospital-based casecontrol study. Nephrourology. 2017;9:e41668.

3. Önen A. Çocuklarda üriner sistem taş hastalığı. Çocuk Cerrahisi Dergisi. 2013;27:8-32.

4. Bal A, Şahbudak Bal Z, Alparslan C, Yavaşcan Ö, Anıl M, Anıl AB. Çocukluk çăgı üriner sistem taş hastalığında etiyolojik faktörler ve tedavi. Turk J Med Sci. 2013;33:1127-32.

5. Matlaga BR, Schaeffer AJ, Novak TE, Trock BJ. Epidemiologic insights into pediatric kidney stone disease. Urol Res. 2010;38:453-7.

6. Ertan P, Tekin G, Oger N, Alkan S, Horasan GD. Metabolic and demographic characteristics of children with urolithiasis in Western Turkey. Urol Res. 2011;39:105-10.

7. Spivacow FR, Del Valle EE, Boailchuk JA, Sandoval Díaz G, Rodríguez Ugarte V, Arreaga Álvarez Z. Metabolic risk factors in children with kidney stone disease: an update. Pediatr Nephrol. 2020;35:2107-12.

8. Izol V, Aridogan IA, Karsli O, Deger M, Satar N. The effect of prophylactic treatment with Shohl's solution in children with cystinuria. J Pediatr Urol. 2013;9:1218-22.
9. Baştuğ F, Düşünsel R. Pediatric urolithiasis: causative factors, diagnosis and medical management. Nat Rev Urol. 2012;9:138-46.

10. Safaei Asl A, Maleknejad S. Pediatric urolithiasis: an experience of a single center. Iran J Kidney Dis. 2011;5:309-13.

11. Santos FMD, Peres AK, Mandotti MR, Peres LAB. Metabolic investigation in patients with nephrolithiasis. Einstein (Sao Paulo). 2017;15:452-56.

12. Pak CY. Citrate and renal calculi: an update. Miner Electrolyte Metab. 1994;20:371-7.

13. Pak CY. Medical management of urinary stone disease. Nephron Clin Pract. 2004;98:49-53.

14. Pak CY, Fuller C, Sakhaee K, Preminger GM, Britton F. Long-term treatment of calcium nephrolithiasis with potassium citrate. J Urol. 1985;134:11-9.

15. Ziemba JB, Matlaga BR. Guideline of guidelines: kidney stones. BJU Int. 2015;116:184-9.

16. Pearle MS, Goldfarb DS, Assimos DG, Curhan G, Denu-Ciocca CJ, Matlaga BR et al; American Urological Assocation. Medical management of kidney stones: AUA guideline. J Urol. 2014;192:31624.

17. Carvalho M, Erbano BO, Kuwaki EY, Pontes HP, Liu JWTW, Boros LH et al. Effect of potassium citrate supplement on stone recurrence before or after lithotripsy: systematic review and meta-analysis. Urolithiasis. 2017;45:449-55.

18. Afshar K, McLorie G, Papanikolaou F, Malek R, Harvey E, Pippi-Salle JL et al. Outcome of small residual stone fragments following shock wave lithotripsy in children. J Urol. 2004;172:1600-3.

19. Tiselius HG. New horizons in the management of patients with cystinuria. Curr Opin Urol. 2010;20:16973.

20. Zu'bi F, Sidler M, Harvey E, Lopes RI, Hojjat A, Naoum $\mathrm{N}$ et al. Stone growth patterns and risk for surgery among children presenting with hypercalciuria, hypocitraturia and cystinuria as underlying metabolic causes of urolithiasis. J Pediatr Urol. 2017;13:357.e1-357.e7. 